\title{
Petrogenetic Significance of Minor Elements in Olivines from Diamonds and Peridotite Xenoliths from Kimberlites of Yakutia.
}

\author{
N. V. Sobolev ${ }^{1}$, D.A. Zedgenizov ${ }^{1}$, A.M. Logvinova $^{1}$, N.P. Pokhilenko ${ }^{1}$, E.V. Malygina ${ }^{1}$, \\ D.V. Kuzmin ${ }^{1,2}$ and A.V. Sobolev ${ }^{2,3}$ \\ ${ }^{1}$ V.S. Sobolev Institute of Geology and Mineralogy, Siberian Branch of Russian Academy of Sciences, \\ Novosibirsk, Russia \\ ${ }^{2}$ Max-Planck Institute of Chemistry, Postfach 3060, Mainz, 55020, Germany \\ ${ }^{3}$ Vernadsky Institute of Geochemistry, Russian Academy of Sciences, 117975, Moscow, Russia \\ (sobolev@uiggm.nsc.ru / Fax: +7 383-3332792 /Phone: +7 383-3332605)
}

Peridotite xenoliths and diamonds from kimberlites represent an important source of information about the composition of the continental lithosphere at depths exceeding 120-150 km. Ultramafic (or peridotitic) $\mathrm{U}(\mathrm{P})$-type of geological environment is dominating at these depths compared to eclogitic (E-type). Olivine is the most typical mineral both of peridotite xenoliths and as diamond inclusion in most kimberlites wordwide. In spite of its simple chemical composition it contains a number of minor elements such as $\mathrm{Ti}, \mathrm{Al}$, $\mathrm{Mn}, \mathrm{Ca}, \mathrm{Cr}, \mathrm{Ni}, \mathrm{Co}$ in low concentrations, mostly below 0.1 wt.\% of oxide except of $\mathrm{NiO}$.

More than 250 diamonds of size range between 0.8 and $3 \mathrm{~mm}$ containing olivine inclusions sometimes associated with enstatite, pyrope, chromediopside and chromite were selected from current diamond production of major Siberian diamond mines. These mines include Mir, Sputnik, Udachnaya, Sytykanskaya kimberlites as well as alluvials of North East of the Siberian craton. Along with earlier studied olivines from diamonds of Yubileynaya, Aykhal, Komsomolskaya and Internatsionalnaya (Sobolev et al., 2008) the present study covers olivine inclusions from all known Siberian diamond mines. Many of them were prepared for analysis of olivines in a single polished surface with diamond. Arkhangelsk diamond mine olivine inclusions (Sobolev et al., 1997) were revised and presented for a comparison. All our revised olivine diamond inclusions data (Sobolev et al., 2008) are summarized in Fig. 1 along with new analytical data. This newly developed data set is represented by 550 analyzed olivines from diamonds. About 200 peridotite xenoliths were selected for olivine studies from a representative collection from unaltered Yakutian kimberlites: Paleozoic Udachnaya diamond mine and Mesozoic Obnazhennaya barren pipe. These xenoliths include mainly samples from Udachnaya (granular lherzolites, harzburgites, dunites and olivine megacrysts) including those diamondiferous. More than 70 xenoliths of porphyroclastic (deformed) lherzolites from Udachnaya are also included into examined collection.
Olivines were analysed for major and minor elements with a JEOL JXA 8200 electron probe at the Max Planck Institute of Chemistry, Mainz. Special efforts were made to obtain high precision and accuracy in electron microprobe analyses, especially, for $\mathrm{Ti}, \mathrm{Al}, \mathrm{Ni}$, Co, Ca, Mn and Cr (Sobolev et al., 2007). These elements were analyzed by using long counting time (120 sec) at $20 \mathrm{kv}$ accelerating voltage and probe current of $300 \mathrm{nA}$ yielding detection limits of around 10-15 ppm and errors of 20-30 ppm (2 standard errors). Minor element abundances of overhelming majority of studied forsteritic (Fo) olivines with Fo $[100 \mathrm{Mg} /(\mathrm{Mg}+\mathrm{Fe})]$ between 86 and 94 vary within the following ranges in wt.\% (NiO 0.310-0.420; $\mathrm{CaO}$ 0.005-0.045; $\mathrm{MnO}$ 0.070-0.131; $\mathrm{Cr}_{2} \mathrm{O} 3$ 0.012-0.117; $\mathrm{CoO}$ 0.008-0.022; $\mathrm{Al}_{2} \mathrm{O}_{3}$ 0.007- 0.059; $\mathrm{TiO}_{2}$ 0.0050.042). No significant differences are noted between Fo in olivine from spinel, pyrope and spinel-pyrope granular lherzolites from Udachnaya mine which cover the range similar to that for diamonds inclusions. However, porphyloclastic (deformed) lherzolites from the same mine contain olivines with very wide and, in general, considerably lower Fo (e.g. Boyd et al., 1997), broad range in $\mathrm{Ca}$ and, especially, Ti. The overhelming majority of diamond inclusion olivines contain very low Ca (less than $200 \mathrm{ppm}$ ) indicating their harzburgitic paragenesis and/or relatively low temperature of equilibrium in lherzolitic paragenesis using Ca-in-olivine thermobarometry (Brey, Köhler, 1990, Köhler, Brey, 1990). Significant positive correlation of Fe and Mn was observed.

In spite of general similarity in Fo and minor element contents in olivines included in diamonds from Siberian mines, the high-precision analysis demonstrates a significant difference for Yubileynaya, the largest Siberian diamond mine, confirming our earlier conclusion (Sobolev et al., 2008). Revised data for olivines from different diamond localities worldwide including Arkhangelsk, Snap Lake and Majghawan kimberlites confirm a conclusion on a dependence of all variations in Fo contents for 

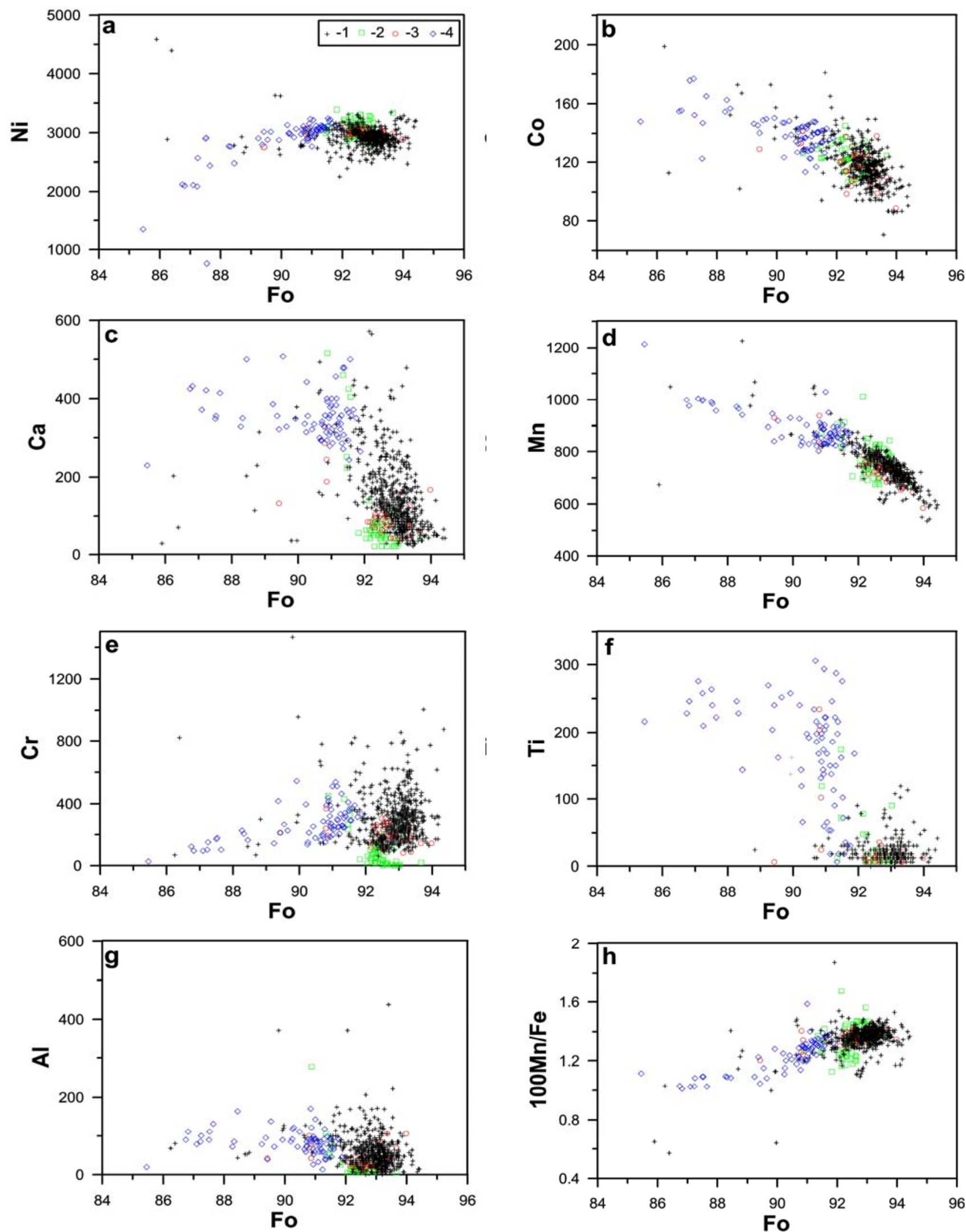

Fig.1. Compositioms of olivines in diamonds from Siberian Craton localities (1), granular lherzolites (2), megacrysts (3) and porphyroclastic (deformed) lherzolites (4) from Udachnaya pipe. Ni (a), Co (b), Ca (c), Mn (d), $\mathrm{Cr}(\mathrm{e}), \mathrm{Ti}$ (f) and $\mathrm{Al}$ (g) contents are presented in $\mathrm{ppm}$ versus forsterite (Fo) contents in mol.\%. 
diamond related olivines on different proportion of lherzolitic and harzburgitic olivines in specific localities (Sobolev et al., 2008). Unusually high $\mathrm{NiO}$ (0.45-0.65 wt.\%) was detected for several low forsteritic (87-89), $\mathrm{CaO}$ (less than $0.02 \mathrm{wt} . \%$ ) and low $\mathrm{MnO}$ (0.07-0.09 wt.\%) olivines from diamonds of different mines. Similar olivine features from mantle magmas argue for the presence of common olivine free mantle source at typical depth of magma generation (e.g. Sobolev et al., 2007). Small fraction of olivine associated with diamonds from Siberian kimberlites yield the same features and thus suggests activity of pyroxenite source at depth over at least $150 \mathrm{~km}$ and likely exceeding $300 \mathrm{~km}$.

\section{References}

Boyd, F.R., Pokhilenko, N.P., Pearson, D.G., et al. , 1997. Composition of the Siberian cratonic mantle: Evidence from Udachnaya peridotite xenoliths. Contrib. Mineral. Petrol., 128, 228-246.

Brey, G.P., \& Köhler, T., 1990. Geothermobarometry in fourphase lherzolites II: new thermobarometers and practical assessment of existing thermobarometers. J. Petrol., 31, 1353-1378.

Köhler, T.P., \& Brey, G.P., 1990. Calcium exchange between olivine and clinopyroxene calibrated as geothermobarometers for natural peridotites from 2 to $60 \mathrm{~kb}$ with applications. Geochim. Cosmochim. Acta, 54, 2375-2388.

Sobolev, A.V., Hofmann, A.W., Kuzmin, D.V., et al., 2007. The amount of recycled crust in sources of mantlederived melts. Science, 316, 412-417.

Sobolev, N.V., Logvinova, A.M., Zedgenizov, D.A., et al., 2008. Olivine inclusions in Siberian diamonds: high precision approach to minor element. Eur. J. Mineral., 20, 305-315.

Sobolev, N.V., Logvinova, A.M., Zedgenizov, D.A., et al., 2000. Anomalous high nickel impurity in olivine inclusions from microdiamonds of Yubileynaya pipe (Yakutia). Doklady Earth Sciences, 375A, 14031406.

Sobolev, N.V., Yefimova, E.S., Reimers, L.F., et al., 1997. Mineral inclusions in diamonds of the Arkhangelsk kimberlite province. Geologiya I Geofizika, 38, 358370 (in Russian). English Translation: Russ. Geol. Geophys., 38, 379-393. 